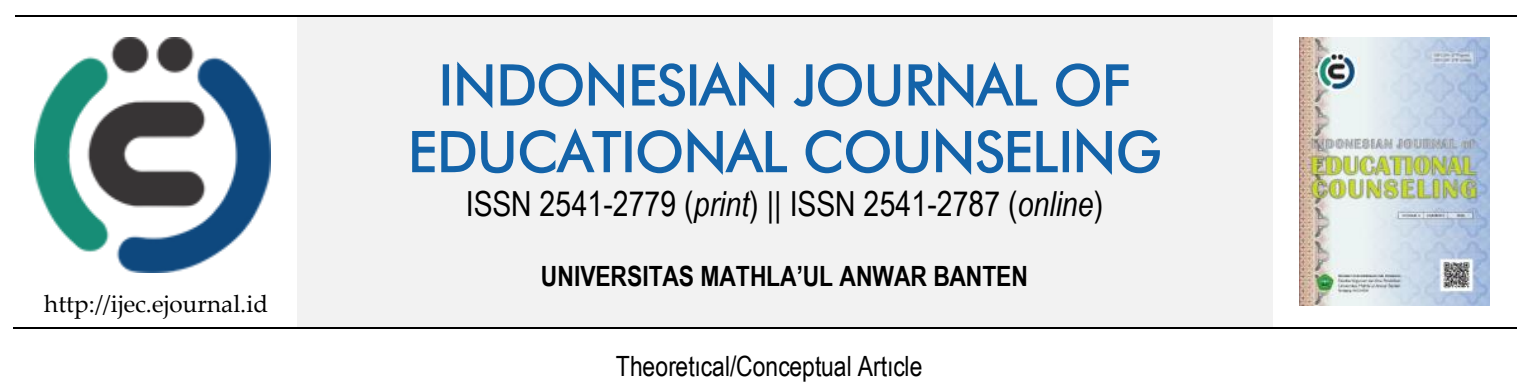

\title{
Urgensi Adaptabilitas dan Resiliensi Karier pada Masa Pandemi
}

\author{
Rina Nurhudi Ramdhani ${ }^{1}$, Andi Kiswanto ${ }^{2}$ \\ ${ }^{1}$ Universitas Pendidikan Indonesia, Indonesia, ${ }^{2}$ Universitas Nahdlatul Ulama Cirebon, Indonesia

\begin{tabular}{ll}
\hline Article History & ABSTRACT \\
\hline Received: 12.05 .2020 & THE IMPORTANCE OF ADAPTABILITY AND CAREER RESILIENCE \\
Received in revised form: & DURING THE PANDEMIC. The main focus of this article is to explore the \\
23.06 .2020 & importance of career adaptability and resilience in dealing with a pandemic. \\
Accepted: 02.07 .2020 & Through various sources of literature it was found that career adaptability and \\
Available online: 20.07 .2020 & $\begin{array}{l}\text { resilience not only as a goal but also as a process. The development of career } \\
\text { adaptability and resilience requires professional intervention through career } \\
\text { guidance and counseling. }\end{array}$
\end{tabular}

KEYWORDS: Career Adaptability, Pandemic, Resilience.

DOI: $10.30653 / 001.202042 .135$

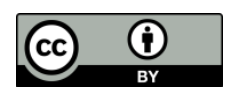

This is an open access article distributed under the terms of the Creative Commons Attribution 4.0 International License, which permits unrestricted use, distribution, and reproduction in any medium, provided the original work is properly cited. ๑ 2020 Rina Nurhudi Ramdhani, Andi Kiswanto.

\section{PENDAHULUAN}

Saat ini kemanusiaan sedang menghadapi masa pandemi yang disebabkan oleh COVID-19. Pandemi berasal dari kata yunani pandemos yang berarti "semua orang". Pandemos adalah konsep adanya kepercayaan bahwa populasi seluruh dunia kemungkinan akan terkena infeksi ini dan sebagian besar dari mereka akan jatuh sakit. Pandemi tumbuh dari epidemi yang merupakan kondisi wabah penyakit menyebar terbatas pada area tertentu di dunia. Sementara itu, pandemi menyebar ke berbagai negara di dunia. Pandemi bukanlah kata yang dapat digunakan secara serampangan. WHO menetapkannya dengan kehati-hatian.

Virus mematikan COVID-19 memiliki efek tular yang sangat cepat dan dapat menular melalui drophlet sehingga berbagai pemerintahan di seluruh dunia secara serempak melakukan apa yang dinamakan dengan physical distancing, guna pencegahan penyebaran maka setiap orang dibatasi dan dilarang berdekatan antara satu dengan yang lain.

Pembatasan yang secara serentak dilaksanakan di seluruh dunia berdampak kepda sosial dan ekonomi semua orang. Banyak orang terpaksa dirumahkan dari pekerjaannya, ekspor dan impor terhenti dan banyak perusahaan juga pada sektor tertentu terpaksa

${ }^{1}$ Corresponding author's address: Program Studi Bimbingan dan Konseling, FIP Universitas Pendidikan Indonesia; Jl. Setiabudi Bandung Email: rinanurhudiramdhani@upi.edu 
gulung tikar. Krisis ini dihadapi oleh semua orang, karena obat maupun vaksin dari virus ini masih belum ditemukan maka yang bisa dilakukan oleh manusia adalah beradaptasi dengan berbagai kebiasaan baru atau disebut dengan "new normal" dan bangkit untuk memperbaiki segala keterpurukan yang dihadapi.

Pada perspekif karier dalam menghadapi masa pandemi ini ada yang disebut dengan adaptabilitas karier dan resiliensi karier. Adaptabilitas adalah kemampuan seseorang beradaptasi dengan lingkungan dan resiliensi adalah kemampuan untuk bangkit kembali dari keterpurukan.

\section{KAJIAN LITERATUR}

\section{Adaptabilitas Karier}

Konsep adaptabilitas karier ini berkembang dari teori career construction yang dikembangkan oleh Savickas. Adaptabilitas karier merupakan komponen ketiga dalam career construction theory (Savickas, 2005, p. 45). Adaptabiltias karier merupakan kesiapan untuk mengatasi tugas yang dapat diprediksi dalam mempersiapkan dan berpartisipasi di dalam peran kerja dan dengan penyesuaian yang tidak dapat diprediksi dikarenakan oleh perubahan kerja dan kondisi kerja. Selain itu Savickas (2005, p. 655) juga mendefinisikan kemampuan beradaptasi karier sebagai kesiapan dan sumber daya untuk membuat pilihan karier dan menegosiasikan transisi karier. Adaptabilitas karier merujuk pada konstruk psikososial yang menunjukkan sumber daya individu untuk mengatasi dan mengantisipasi tugas-tugas saat ini, transisi, trauma dalam peran pekerjaannya (Savickas \& Porfeli, 2012, p. 662). Adaptabilitas karier juga berarti kapasitas khusus untuk mengasah dan menggunakan sumber daya psikososial yang diperlukan untuk membuat perubahan dalam diri dan situasi untuk kepuasan dan kesuksesan karier (Hartung \& Cadaret, 2017, p. 15).

Berdasarkan hal itu maka kemampuan beradaptasi karier adalah konstruksi psikososial yang mencakup kemampuan dan sikap orang dalam mempersiapkan perubahan karier dan transisi karier (Savickas, 2005). Konstruk psikososial tersebut dipaparkan dalam keempat dimensi adaptabilitas karier yakni concern, control, curiosity dan confidence.

Menurut Rottinghaus, Day, dan Borgen (2005, p. 5) mendefinisikan adaptabilitas karier sebagai kecenderungan yang memengaruhi cara individu memandang kemampuannya untuk merencanakan dan menyesuaikan diri dengan perubahan rencana karier terutama dalam menghadapi kejadian tak terduga. Adaptasi karier dikonseptualisasikan juga sebagai model agregat, di mana kesiapan pilihan, perencanaan, eksplorasi, dan keyakinan bersama-sama menghasilkan adaptasi karier tinggi (Hirschi, 2009, p. 149). Adaptasi karier dihasilkan dari keterlibatan aktif dalam interaksi yang bermakna antara orang dan lingkungan. (Hirschi, 2009, p. 153). Adaptabilitas karier merupakan sikap, kompetensi, dan perilaku yang digunakan individu dalam menyesuaikan diri dengan pekerjaan yang sesuai dengan dirinya. Kemampuan beradaptasi menekankan proses coping di mana individu terhubung ke komunitas dan membangun karier (Andersen \& Vandehey, 2012, p. 61).

Creed, Fallon \& Hood (2009, p. 222) mengoperasionalkan adaptabilitas karier sebagai perencanaan karier (career planning), eksplorasi diri (self exploration), eksplorasi 
lingkungan karier (environment-career exploration), pengambilan keputusan (decision making), dan regulasi diri (self regulation). Berdasarkan definisi tersebut dapat diketahui bahwa (a) perencanaan karier melibatkan orientasi dan pengetahuan masa depan tentang tindakan apa yang diperlukan untuk mengejar tujuan; (b) eksplorasi diri berfokus untuk mengeksplorasi kepentingan, pengalaman dan nilai pribadi, untuk lebih memahami diri di dunia karier; (c) eksplorasi lingkungan melibatkan mengumpulkan informasi yang relevan dengan pengembangan karier ; (d) pengambilan keputusan melibatkan evaluasi pengetahuan dan alternatif yang mendukung hasil yang dirasakan individu yang dapat dilakukan; dan (e) pengaturan diri mencakup banyak sekali proses dimana individu memberikan kontrol atas impuls, pemikiran, perasaan dan penampilan tugas untuk mencapai tujuan yang ditetapkan untuk dirinya sendiri. Pengaturan diri meningkatkan kemampuan individu untuk menyesuaikan diri dengan beragam tuntutan situasional dan sosial. (Creed, Fallon, \& Hood, 2009, p. 220) Karier dan eksplorasi diri dan perencanaan karier adalah kegiatan seumur hidup yang penting untuk transisi karier, dan dapat dicirikan sebagai proses adaptif. Hal tersebut sejalan dengan pendapat Savickas \& Porfeli (2012) yang menyatakan bahwa kemampuan beradaptasi karier adalah kompetensi transaksional yang dikembangkan berdasarkan pengalaman dari waktu ke waktu, dibentuk dengan pembelajaran, dan ditambah dengan kemampuan lain.

Adaptabilitas berkembang melalui interaksi antara dunia dalam pribadi dan dunia luar pribadi (Savickas \& Porfeli, 2012, p. 663) dan sumber daya ini tidak menjadi inti dari individu, melainkan individu berada sebagai persimpangan orang dalam lingkungan. Dengan demikian, kemampuan beradaptasi adalah konstruksi psiko-sosial (Savickas \& Porfeli, 2012, hlm 662). Berdasarkan hal itu maka dapat diketahui bahwa kemampuan adaptabilitas karier dipengaruhi oleh faktor internal dan eksternal. Faktor internal yang memengaruhi adaptabilitas karier antara lain gender (Hirschi, 2009, p. 145), usia (Hirschi, 2009, p. 145; Rottinghaus, 2017, p. 101), kepribadian (Bullock-Yowell, Andrews \& Buzzeta, 2011, p. 400), self efficacy, dan status sosial ekonomi (Rottinghaus, 2017, p. 101). Sedangkan faktor eksternal yang memengaruhi adaptabilitas karier antara lain pola pengasuhan orang tua, dan dukungan dari keluarga (Guan,Wang, et al., 2015, p. 230; Tian \& Fan, 2014, p. 251) kedekatan anak dengan keluarga, pengalaman kerja sebelumnya, pengalaman bersekolah sebelumnya. (Sisca \& Gunawan, 2015, p. 113). Faktor-faktor tersebut secara lebih rinci dijelaskan sebagai berikut.

\section{Gender}

Perbedaan gender diketahui secara signifikan berbeda dalam kemampuan adaptabilitas karier meskipun ukuran efek nya hanya sedikit. Berdasarkan penelitian Vilhjahlmsdottir (2017, p. 393) perempuan secara signifikan lebih tinggi daripada laki-laki dalam ketiga dimensi adaptabilitas karier yakni concern, cooperation dan contribution. Hal ini dikarenakan perempuan membutuhkan keseimbangan yang lebih dalam menyeimbangkan peran dalam keluarga dan pekerjaannya.

\section{Usia}

Perbedaaan usia memengaruhi adaptabilitas karier seseorang. Berdasarkan penelitian Vilhjahlmsdottir (2017, p. 392) diketahui bahwa kelompok usia muda (15-20 tahun) memiliki concern (perencanaan) dan curiosity (exploration) yang tinggi. Sedangkan kelompok usia yang lebih tua memiliki control yang lebih tinggi. Hal ini menunjukkan bahwa orang muda dihadapkan pada tugas perkembangan, atau tugas yang perlu 
dipecahkan yang memerlukan perhatian dan rasa ingin tahu sedangkan orang tua diharuskan untuk lebih mengendalikan saat beradaptasi dengan karier. Penelitian Ambiel et al (2016, p. 16) juga menghasilkan temuan mengenai perbedaan usia yang memengaruhi adaptabilitas karier . Menurut temuan Ambiel et al (2016, p. 16) orang dewasa memiliki score yang lebih tinggi dalam skala CAAS-I yang menjadi instrumen dalam penelitiannya.

\section{Kepribadian}

Kepribadian diketahui memiliki hubungan dengan adaptabilitas karier (BullockYowell, Andrews \& Buzzeta, 2011, p. 400 dalam Sisca \& Gunawan, 2015, p. 113). Kemampuan beradaptasi karier secara positif meramalkan kepuasan karier dan self-rated kinerja karier yang tinggi dan melampaui lima karakter kepribadian dan evaluasi diri inti (Zacher, 2014, p. 27). Terkait dengan big five personality, kelima dimensi yakni kesesuaian, kesadaran, ekstraversi, stabilitas emosional, dan keterbukaan berhubungan positif dengan kemampuan beradaptasi karier . Demikian juga, harga diri berhubungan positif dengan kemampuan beradaptasi karier ), seperti juga evaluasi diri inti, kepribadian proaktif, orientasi masa depan, harapan, dan optimisme (Rudolph, Lavigne \& Zacher, 2016, p. 18).

Orang cenderung tertarik pada lingkungan kerja yang, setidaknya sampai tingkat tertentu, sesuai dengan kepribadiannya (Barrick, Mount, \& Gupta, 2003, p. 45). Dalam studi Tien dkk (2013), kepribadian juga diyakini sebagai faktor penting yang terkait dengan kemampuan beradaptasi karier . Penelitian Teixeira et al (2012, p. 680) menunjukkan bahwa kemampuan beradaptasi karier berkorelasi positif dengan ciri kepribadian seperti ekstraversi, kesadaran, kesesuaian, dan keterbukaan yang dialami dalam sampel Brasil. Van Vianen, Klehe, Koen, dan Dries (2012, p. 716) menemukan hubungan yang serupa antara kemampuan beradaptasi karier dan lima karakter dalam peserta Belanda. Banyak penelitian menunjukkan bahwa ciri kepribadian terus berubah selama masa dewasa, terutama pada usia 20-40 tahun (Roberts, Robins, Caspi, \& Trzesniewski, 2003, p. 579).

\section{Self-efficacy}

Self-efficacy didefinisikan sebagai keyakinan individu terhadap kemampuannya untuk tampil dengan baik dalam beberapa tugas tertentu. Beberapa penelitian menunjukkan bahwa terdapat hubungan kausalitas antara adaptabilitas karier dengan karier self-efficacy individu (Tien et al, 2013), adaptabilitas karier dan self efficay berhubungan dengan penyesuaian kerja pada pekerja dewasa (Yang et al, 2015, p. 21), selain itu adaptabilitas karier juga diketahui mendukung self efficacy dalam pencarian kerja (Guan et al, 2013, 561) dan secara positif memprediksi keterampilan kerja (de Guzman \& Choi, 2013, p. 199).

\section{Status Ekonomi dan Sosial}

Status ekonomi diketahui mempunyai pengaruh penting dalam karier seseorang. (Patton \& Lokan, 2011, p. 18). Konseli yang berasal dari latar belakang ekonomi kurang mungkin merasakan penurunan rasa otonomi mengenai masa depan. Kurangnya fleksibilitas finansial dapat membuat pemikiran berorientasi masa depan dan juga rasa kontrol yang sulit saat mengeksplorasi pilihan karier potensial. Kemudian orientasi budaya individualistis atau kolektivisme juga dapat memengaruhi rasa kontrol konseli. 
Konseli dengan perspektif kolektivis mungkin menghargai pendapat dan keinginan keluarga asal tentang masa depan karier secara setara atau mungkin lebih dari sekedar pengalamannya sendiri. (Rottinghaus et al, 2017, p. 96).

\section{Keluarga}

Dukungan sosial orang lain memengaruhi eksplorasi karier orang dewasa muda (Creed, Fallon, \& Hood, 2009, p. 221). Keluarga merupakan faktor penting yang berdampak pada adaptabilitas karier. Keluarga memiliki pengaruh langsung dalam proses perkembangan karier individu (Bergen, 2006 dalam Sisca \& Gunawan, p. 113). Dukungan keluarga merupakan prediktor perkembangan karier adaptif yang signifikan (Hirschi, 2009, p. 145) dan memiliki keterlibatan dalam persiapan karier remaja (Hirschi, Niles \& Akos, 2011, 173). Berdasarkan penelitian diketahui bahwa dukungan keluarga terkait dengan pengembangan karier mahasiswa (Metheny \& McWhirter, 2013, 387), dan variabel proses dalam keluarga seperti kehangatan, dukungan, keterikatan, otonomi memengaruhi serangkaian konstruksi karier (Whiston \& Keller, 2004, p. 558).

\section{Institusi Pendidikan}

Institusi pendidikan yang dipilih oleh seseorang memiliki peranan penting dalam adaptabilitas karinya (Paton dan Lokan, 2011 dalam Angelia, p. 17). Pendidikan berhubungan positif dengan kemampuan beradaptasi karier sesuai dengan asumsi bahwa modal manusia berkontribusi terhadap kemampuan beradaptasi karier (Rudolph, Lavigne \& Zacher, 2016, p. 25).

Dimensi adaptabilitas karier antara lain concern, control, curiosity, and confidence. Keempat dimensi ini mewakili sumber dan strategi adaptif umum yang digunakan individu untuk mengelola tugas, transisi, dan trauma kritis saat individu membangun karier nya. Individu yang adaptif dikonseptualisasika menjadi concern tentang masa depan sebagai pekerja, meningkatkan control pribadi atas masa depan kejuruan, menunjukkan curiosity dengan mengeksplorasi kemungkinan diri dan skenario masa depan, dan memperkuat confidence untuk mengejar aspirasinya.

Perkembangan sepanjang empat dimensi adaptasi berkembang dengan tingkat yang berbeda, dengan kemungkinan fiksasi dan regresi. Keterlambatan di dalam atau disekuilibrium di antara empat garis perkembangan menghasilkan masalah dalam mengkristalkan preferensi karier dan menentukan pilihan pekerjaan, masalah yang dikemukakan oleh konselor karier sebagai ketidakpedulian, keraguan, tidak realistis, dan penghambatan. Membandingkan pengembangan di antara empat dimensi adalah cara yang berguna untuk menilai kemampuan beradaptasi karier dan untuk memahami pendahuluan kesulitan dalam pengambilan keputusan kejuruan dan masalah penyesuaian kerja. (Savickas, 2005, p. 56).

Deskripsi terkait masing-masing dimensi career adaptability (Savickas, 2005, p. p. 5256) dipaparkan sebagai berikut.

1) Career concern. Concern individu tentang masa depan kejuruannya sendiri adalah dimensi pertama dan terpenting dari kemampuan beradaptasi karier . Career concern pada dasarnya berorientasi pada masa depan, sehingga individu merasa bahwa penting untuk mempersiapkan diri untuk hari esok. Sikap planfulness dan optimis menumbuhkan sense of concern karena membuat individu menyadari tugas kejuruan dan transisi pekerjaan yang harus dihadapi dan pilihan yang harus dibuat dalam 
waktu dekat. Career concern membuat masa depan terasa nyata karena membantu seseorang mengingat masa kejuruan, mempertimbangkan saat-saat kejuruan, dan mengantisipasi masa depan kejuruan. Berpikir tentang kehidupan kerjanya sepanjang waktu adalah inti karier karena karier subyektif bukanlah perilaku; Ini adalah sebuah gagasan - sebuah refleksi tentang diri. Concern memiliki keterkaitan kuat dan positif terhadap kepuasan karier, affective dan normative organizational commitment, calling, dan identitas karier (Rudolph, C.W., Lavigne, K.N., Katz, I. M., \& Zacher, H, 2017, p. 8; Kiswanto, A. : 2014) dan memiliki hubungan negatif dengan keinginan berpindah pekerjaan (turnover intentions). Kurangnya perhatian karier disebut career indifference atau ketidakpedulian karier, dan ini mencerminkan ketidakberdayaan dan pesimisme tentang masa depan.

2) Career control. Kontrol atas masa depan kejuruan individu adalah dimensi terpenting kedua dalam kemampuan beradaptasi karier . Kontrol karier berarti individu merasa dan percaya bahwa dirinya bertanggung jawab untuk membangun karier. Sikap asertif dan ketegasan menyingkirkan individu yang mengatur diri sendiri untuk melibatkan tugas pengembangan kejuruan dan menegosiasikan transisi pekerjaan, bukan menunda-nunda dan menghindarinya. Sikap asertif dan kepercayaan terhadap tanggung jawab pribadi membuat individu cenderung terlibat dalam aktivitas dan pengalaman yang mendorong ketegasan dan kompetensi dalam pengambilan keputusan. Kurangnya kontrol karier sering disebut career indecision atau keraguraguan karier. Ketidakmampuan untuk memilih dapat diatasi dengan intervensi karier yang dirancang untuk mendorong sikap menentukan dan kompetensi keputusan.

3) Career curiosity. Dengan rasa kontrol, datanglah inisiatif untuk mempelajari jenis pekerjaan yang mungkin ingin dilakukan individu dan kesempatan kerja untuk melakukannya. Career curiosity mengacu pada keingintahuan tentang dan eksplorasi kecocokan antara diri dan dunia kerja. Saat ditindaklanjuti, rasa ingin tahu menghasilkan dana pengetahuan untuk membuat pilihan yang sesuai dengan situasi. Eksplorasi dan refleksi sistematis terhadap pengalaman penjelajahan acak menggerakkan individu dari naif ke pengetahuan saat individu mempelajari bagaimana dunia bekerja. Kurangnya keingintahuan karier dapat menyebabkan naiveté tentang dunia kerja dan citra diri yang tidak akurat. Naivate ini dapat diatasi dengan intervensi karier yang dirancang untuk memberikan informasi.

4) Career confidence. Dimensi keempat dan terakhir dari kemampuan beradaptasi karier adalah kepercayaan diri. Keyakinan diri menunjukkan antisipasi kesuksesan dalam menghadapi tantangan dan mengatasi rintangan (Rosenberg, 1989). Pilihan karier memerlukan pemecahan masalah yang kompleks. Perlu kepercayaan diri untuk melakukan apa yang dibutuhkan untuk menguasai masalah ini. Kurangnya kepercayaan karier dapat mengakibatkan career inhibition atau penghambatan karier yang menggagalkan peran aktual dan mencapai tujuan. Intervensi konseling karier , secara umum, membangun kepercayaan diri melalui dimensi hubungan konseling. Sikap coping, kepercayaan, dan kompetensi memperkuat kepercayaan karier dan mengarah langsung pada keterlibatan dan penguasaan tugas pengembangan kejuruan, transisi pekerjaan, dan trauma pribadi. 


\section{Resiliensi Karier}

Perspektif psikologis menggambarkan bahwa resiliensi merupakan dinamika proses individu menggambarkan adaptasi positif berdasarkan pengalaman negatif atau trauma (Luthar \& Cicchetti: 2000). Dengan kata lain dapat dikatakan bahwa resiliensi adalah kemampuan untuk "bangkit kembali" dari kesulitan maupun kemunduran bahkan mampu bertumbuh dan menguat sebagai hasil dari penyesuaian (Luthans et al, 2006).

Sedangkan perspektif karier resiliensi berfokus pada pembelajaran berkelanjutan, adaptasi terhadap perubahan, manajemen karier mandiri, dan pemenuhan kebutuhan pasar yang selalu berubah, semua adalah sumber keunggulan kompetitif bagi seseorang yang bersaing dalam ekonomi secara global (Waterman, Waterman, \& Collard: 1994). Walaupun resiliensi secara psikologis dikaitkan dengan dampak positif pada pekerjaan, akan tetapi resiliensi karier dengan sudut pandang yang lebih luas dianggap sebagai sebuah kompetensi pada karier modern.

London (1983) mendefinisikan resiliensi karier sebagai "resistensi seseorang terhadap gangguan karier dalam lingkungan yang kurang optimal".

Hasil dari resiliensi, ia berpendapat, adalah peningkatan kemampuan untuk mengatasi pengalaman karier yang negatif. Orang-orang yang lebih tangguh dalam karier mereka berteori untuk menunjukkan inisiatif, kepercayaan diri, kreativitas, pengambilan risiko, pekerjaan berkualitas, pengembangan diri, kinerja tinggi, dan tingkat absensi rendah dalam menghadapi kendala situasional seperti tekanan waktu, sumber daya yang tidak mencukupi. , dan ambiguitas peran (London, 1983; Noe, Noe, \& Bachhuber, 1990).

London (1983) berpendapat bahwa resiliensi karier terdiri dari tiga subdomain: (1) kemanjuran diri, yang meliputi harga diri, kebutuhan akan otonomi, kemampuan beradaptasi, kontrol internal, kebutuhan untuk pencapaian, inisiatif, kebutuhan kreativitas, standar kerja dalam ( yaitu, termotivasi diri untuk melakukan pekerjaan yang berkualitas), dan orientasi pengembangan (yaitu, keinginan untuk memperluas keterampilan atau pengetahuan seseorang); (2) pengambilan risiko, termasuk kecenderungan pengambilan risiko, ketakutan akan kegagalan, membutuhkan keamanan, dan toleransi terhadap ketidakpastian dan ambiguitas; dan (3) ketergantungan, yang meliputi ketergantungan karier, kebutuhan akan persetujuan superior, kebutuhan akan persetujuan rekan kerja dan daya saing.

Fourie dan Van Vuuren (1998) mendefinisikan resiliensi karier sebagai proses mengatasi kesulitan karier yang terus-menerus dan episodik, termasuk hilangnya keterikatan di tempat kerja, hilangnya keamanan, ambiguitas. tentang jalur karier, tingkat stres yang tinggi dan kesulitan dalam menyeimbangkan peran pekerjaan dan nonpekerjaan. Resiliensi karier melibatkan sejumlah perilaku, termasuk: adaptasi terhadap perubahan keadaan; menyambut perubahan pekerjaan dan organisasi, merangkul bekerja dengan orang-orang baru dan berbeda; menunjukkan kepercayaan diri; dan kesediaan untuk mengambil risiko. Ini juga menyiratkan rasa takut yang rendah akan kegagalan, rendahnya kebutuhan akan keamanan dan toleransi yang tinggi terhadap ketidakpastian dan ambiguitas. VanVuuren dan Fourie (1998) mengembangkan ukuran resiliensi karier dan menemukan itu memiliki empat faktor: (1) kepercayaan pada diri sendiri; (2) mengabaikan sumber tradisional kesuksesan karier; (3) kemandirian; dan (4) penerimaan untuk berubah. 
Resiliensi karier merupakan Konstruk untuk Menangani Tantangan Masa Depan. Resiliensi karier adalah "payung konseptual yang luas, mencakup banyak konsep yang berkaitan dengan pola adaptasi positif dalam konteks kesulitan" (Masten \& Obradović, 2006, hal. 14).

Alih-alih dikonseptualisasikan sebagai sifat yang stabil, resiliensi karier didefinisikan sebagai kemampuan yang dapat dikembangkan, melalui pengulangan dan adaptasi terhadap kesulitan (Seery, Holman, \& Silver, 2010). Sebagai hasil dari ancaman dan tingginya resiko yang terkait dengan sosial dan pekerjaan (Dagdeviren, Donoghue, \& Promberger, 2016) ketidakpastian dan meningkatnya tekanan organisasi, resiliensi karier lebih menonjol di bidang pengembangan karier (Di Maggio, Ginevra, Nota, \& Soresi, 2016).

Di Maggio et al. (2016) mengamati bahwa resiliensi karier berkorelasi positif dengan dimensi psikologis berbeda yang relevan untuk konstruksi dan pengembangan karier, seperti orientasi masa depan, harapan, optimisme, dan kemampuan adaptabilitas karier. Demikian pula, Barto, Lambert, dan Brott (2015) menemukan bahwa resiliensi berkorelasi positif dengan kemampuan adaptabilitas karier, dan kedua konstruksi ini membantu dalam mengatasi hambatan karier.

\section{DISKUSI}

Lingkungan karier pada dunia modern sangatlah dinamis penuh gejolak dan stres, jika ditambahkan dengan masa pandemi merupakan kombinasi yang dapat menyebabkan banyak orang terpuruk dalam karier. Menghadapi berbagai permasalahan dalam masa pandemi menuntut setiap orang untuk mengembangkan kemampuan adaptasi dan resiliensi karier. Kedua kemampuan tersebut membuat seseorang semakin tangguh dalam menghadapi kesulitan dan gangguan, semakin memperbesar juga kemungkinan seseorang untuk bertahan terhadap tujuan-tujuan karier (London, 1983).

Sumber daya pribadi yang diuraikan dalam bab ini (yaitu kemampuan beradaptasi dan resiliensi karier) sangat penting ketika orang menghadapi masa pandemi karena kemampuan tersebut dapat membantu seseorang mengelola jalur karier dan meningkatkan kepribadian dan profesional dengan baik walaupun dalam keadaan terburuk sekalipun. Untuk alasan ini, intervensi yang spesifik harus dikembangkan dan diterapkan untuk meningkatkan sumber daya pribadi ini. Paradigma life design menekankan intervensi seumur hidup, holistik, kontekstual, dan preventif (Savickas et al., 2009). Karenanya intervensi karier harus tersedia sepanjang hayat dan membantu individu untuk mengidentifikasi dan mengembangkan keterampilan dan kekuatan dalam membantu pencapaian tujuan yang bermakna. Individu harus didorong untuk mempertimbangkan semua peran hidup mereka, di luar konteks pekerjaan. Pentingnya konteks di mana individu hidup juga harus dipertimbangkan, dan dari perspektif ini, intervensi harus inklusif dan mempertimbangkan faktor kontekstual. Terakhir, intervensi juga memiliki peran preventif, mempromosikan sikap, pengetahuan dan perilaku yang berguna untuk meningkatkan kesejahteraan pribadi dan profesional dalam jangka panjang (Nota et al., 2015).

Intervensi secara spesifik melalui pendekatan konseling sangat efektif dalam proses pengembangan emosi yang positif. Tugade dan Frederickson (2004) menunjukkan bahwa emosi positif membantu membangun adaptabilitas dan resiliensi karier dengan 
memperluas repertoar pikiran dan tindakan individu dalam menghadapi kesulitan. Dengan demikian, intervensi seperti terapi perilaku kognitif, yang berfokus pada mengubah kognisi untuk meningkatkan pengaruh positif, dapat membantu dalam membangun resistensi terhadap kesulitan karier. Meskipun pengembangan dalam membangun adaptabilitas dan resiliensi karier pada masa pandemi adalah tugas semua orang dan tidak akan pernah ada habisnya atau mungkin pekerjaan yang sedang berlangsung, ini menunjukkan bahwa intervensi seperti itu memang diperlukan dalam lingkungan karier modern dan dibutuhkan pada masa pandemi. Bimbingan dan konseling karier merupakan strategi dan pendekatan yang dapat digunakan dalam pelaksanaannya.

\section{SIMPULAN}

Kemampuan adaptabilitas dan resiliensi karier dalam menghadapi masa pandemi dibutuhkan. Karier bukan hanya sebagai tujuan untuk mendapatkan kesuksesan. Pada prosesnya karier juga membutuhkan well being dan emosi yang positif, karena kedua hal tersebut dapat mempengaruhi kemampuan adaptasi dan resiliensi karier seseorang. Berbagai intervensi karier dibutuhkan dalam pencapaian prosesnya, terutama bimbingan dan konseling karier. Bantuan pihak profesional dalam masa pandemi sangat dibutuhkan karena tidak mudahnya bagi setiap orang menghadapi keterpurukan pada masa pandemi ini.

Kerangka teoritis holistik dan intervensi untuk adaptabilitas dan resiliensi karier dipromosikan dalam bimbingan dan konseling karier. Adaptabilitas dan resiliensi karier penting untuk menghubungkan dan menyusun cara yang bermakna dalam kehidupan untuk mempertahankan integritas dan kontinuitas diri paska pandemi. Adaptasi dan resiliensi karier adalah sumber daya yang menopang kemampuan kerja dan mempromosikan kehidupan yang sukses, tetapi sumber daya ini juga penting di tingkat kolektif untuk mempromosikan kehidupan yang layak pada skala yang lebih besar terutama kemanusian di masa pandemi.

\section{REFERENSI}

Ambiel, R. A., de Francisco Carvalho, L., Martins, G. H., \& Tofoli, L. (2016). Comparing the adaptabilities of Brazilian adolescent students and adult workers. Journal of Vocational Behavior, 94, 20-27. doi: 10.1016/j.jvb.2016.02.005.

Andersen, P \& Vandehey, M. (2012). Career Counseling and Development in a Global Economy, 2nd Edition. USA: Brooks/Cole.

Creed, P. A., Fallon, T., \& Hood, M. (2009). The relationship between career adaptability, person and situation variables, and career concerns in young adults. Journal of Vocational Behavior, 74(2), 219-229.

Dagdeviren, H., Donoghue, M., \& Promberger, M. (2016). Resilience, hardship and social conditions. Journal of Social Policy, 45, 1-20. doi: 10.1017/S004727941500032X. 
Di Maggio, I., Ginevra, M. C., Nota, L., \& Soresi, S. (2016). Development and validation of an instrument to assess future orientation and resilience in adolescence. Journal of Adolescence, 51, 114-122. doi: 10.1016/j.adolescence.2016.06.005.

Fourie, C., \& Van Vuuren, L. J. (1998). Defining and measuring career resilience. SA Journal of Industrial Psychology, 24(3), 52-59.

Guan, Y., Zhou, W., Ye, L., Jiang, P., \& Zhou, Y. (2015). Perceived organizational career management and career adaptability as predictors of success and turnover intention among Chinese employees. Journal of Vocational Behavior, 88, 230-237. doi: 10.1016/j.jvb.2015.04.002.

Guan, Y., Deng, H., Sun, J., Wang, Y., Cai, Z., Ye, L., ... \& Li, Y. (2013). Career adaptability, job search self-efficacy and outcomes: A three-wave investigation among Chinese university graduates. Journal of Vocational Behavior, 83(3), 561-570.

Hartung, P. J., \& Cadaret, M. C. (2017). Career adaptability: Changing self and situation for satisfaction and success. In K. Maree (ed), Psychology of career adaptability, employability and resilience (pp. 15-28). Cham: Springer.

Hirschi, A. (2009). Career adaptability development in adolescence: Multiple predictors and effect on sense of power and life satisfaction. Journal of Vocational Behavior, 74(2), 145-155. doi: 10.1016/j.jvb.2009.01.002.

Hirschi, A. (2010). Swiss adolescents' career aspirations: Influence of context, age, and career adaptability. Journal of Career Development, 36(3), 228-245. doi: 10.1177/0894845309345844.

Kiswanto, A. (2014). Program Bimbingan Karier untuk mengembangkan Identitas Karier Mahasiswa (Tesis Magister, Universitas Pendidikan Indonesia).

London, M. (1983). Toward a theory of career motivation. Academy of Management Review, 8(4), 620-630.

London, M. (1993). Relationships between career motivation, empowerment and support for career development. Journal of occupational and organizational psychology, 66(1), 55-69.

London, M., \& Noe, R. A. (1997). London's career motivation theory: An update on measurement and research. Journal of Career Assessment, 5(1), 61-80.

Luthans, F., Vogelgesang, G. R., \& Lester, P. B. (2006). Developing the psychological capital of resiliency. Human Resource Development Review, 5(1), 25-44.

Luthar, S. S., \& Cicchetti, D. (2000). The construct of resilience: Implications for interventions and social policies. Development and Psychopathology, 12(4), 857-885. 
Metheny, J., \& McWhirter, E. H. (2013). Contributions of social status and family support to college students' career decision self-efficacy and outcome expectations. Journal of Career Assessment, 21(3), 378-394.

Noe, R. A., Noe, A. W., \& Bachhuber, J. A. (1990). An investigation of the correlates of career motivation. Journal of Vocational Behavior, 37(3), 340-356.

Nota, L., Ginevra, M. C., \& Santilli, S. (2015). Life design and prevention. In L. Nota \& J. Rossier (Eds.), Life design handbook: From practice to theory and from theory to practice (pp. 183-199). Göttingen, Germany: Hogrefe.

Ramdhani, R. N., Budiamin, A., \& Budiman, N. (2019). Adaptabilitas Karier Dewasa Awal. Jurnal Penelitian Pendidikan, 18(3), 361-370.

Rottinghaus, P. J., Day, S. X., \& Borgen, F. H. (2005). The career futures inventory: A measure of career-related adaptability and optimism. Journal of Career Assessment, 13(1), 3-24.

Rudolph, C. W., Lavigne, K. N., \& Zacher, H. (2017). Career adaptability: A metaanalysis of relationships with measures of adaptivity, adapting responses, and adaptation results. Journal of Vocational Behavior, 98, 17-34. doi: 10.1016/j.jvb.2016.09.002

Rudolph, C. W., Lavigne, K. N., Katz, I. M., \& Zacher, H. (2017). Linking dimensions of career adaptability to adaptation results: A meta-analysis. Journal of Vocational Behavior, 102, 151-173. doi: 10.1016/j.jvb.2017.06.003.

Savickas, M. L. (1997). Career adaptability: An integrative construct for life-span, lifespace theory. Career Development Quarterly, 45, 247-259. Doi: 10.1002/j.21610045.1997.tb00469.x.

Savickas, M. L. (2005). The theory and practice of career construction. In S.D. Brown \& R.W. Lent (Eds), Career development and counselling: Putting theory and research to work (pp 42-70). Hoboken, NJ: Wiley.

Savickas, M. L., Nota, L., Rossier, J., Dauwalder, J.P., Duarte, M.E., Guichard, J., Soresi, S., Esbroeck, R.V., \& Vianen, A.E.M.V. (2009). Life Designing: A paradigm for career construction in the 21st century. Journal of Vocational Behavior, 75, 239-250.

Savickas, M. L., \& Porfeli, E. J. (2012). Career Adapt-Abilities Scale: Construction, reliability, and measurement equivalence across 13 countries. Journal of Vocational Behavior, 80(3), 661-673. doi: 10.1016/j.jvb.2012.01.011.

Seery, M. D., Holman, E. A., \& Silver, R. C. (2010). Whatever does not kill us: cumulative lifetime adversity, vulnerability, and resilience. Journal of Personality and Social Psychology, 99(6), 1025-1041. doi: 10.1037/a0021344. 
Vilhjálmsdóttir, G., Kjartansdóttir, G. B., Smáradóttir, S. B., \& Einarsdóttir, S. (2012). Career adapt-abilities scale-Icelandic form: Psychometric properties and construct validity. Journal of Vocational Behavior, 80(3), 698-704. doi: 10.1016/j.jvb.2012.01.013.

Tugade, M. M., \& Fredrickson, B. L. (2004). Resilient individuals use positive emotions to bounce back from negative emotional experiences. Journal of Personality and Social Psychology, 86(2), 320-333.

Vilhjálmsdóttir, G. (2017). Career changes on the horizon: The importance of group norms in interpreting results of career adaptability measures. In K. Maree (ed), Psychology of career adaptability, employability and resilience (pp. 375-396). Cham: Springer.

Bullock-Yowell, E., Andrews, L., \& Buzzetta, M. E. (2011). Explaining career decisionmaking self-efficacy: Personality, cognitions, and cultural mistrust. The Career Development Quarterly, 59(5), 400-411.

Zacher, H. (2014). Career adaptability predicts subjective career success above and beyond personality traits and core self-evaluations. Journal of Vocational Behavior, 84(1), 21-30. doi: 10.1016/j.jvb.2013.10.002. 